\title{
A CHANGE IN ATTITUDES TO SEMI-ARID LAND USE IN THE HAKATARAMEA VALLEY
}

\section{BROSNAN}

Riverside, Hakataramea Valley

Abstract

During the recent drought in the Kurow area, shallow rooting grasses. clovers and weeds died, pastures were overgrazed and massive wind erosion problems occurred, I have overdrilled more than 100 hectares of lucerne with various drought tolerant grasses, including wheatgrass, phalaris, cocksfoot, prairie grass and tall fescue.

My grazing management has changed and I am introducing earthworms into the paddocks. Last spring I started fencing and planting the sunny faces with shrubs and eventually I intend to space plant the shady faces with a multi-use, high value timber species.

My revegetation plan meets the aims of the Resource Conservation Committee which is to promote a more sustainable land use system, with the capacity to produce a diversity of products, and make the beautiful Haka Valley a better place for animals and people to live, now and in the future. This form of integrated farming and "working with nature" seems to lead the way to a more sustainable farming system which not only protects the land for today but nourishes it for generations to come.

Keywords: conservation, wind erosion, dryland grasses, browse shrubs.

\section{INTRODUCTION}

I am often called a "Greenie" and feel very comfortable with this title. Now, there are two types of greenie: the type that talks about what should be done and the type who is out there with mud on hands proving that conservation systems actually work.

This paper outlines an attempt to turn our farm, Riverside, into a conservation demonstration property, within the confines of the prevailing economic situation; in other words, to show that conservation methods, or working with nature rather than against it, actually pays.

Encouraged by past government policies, some of us, and in particular the more progressive, have pushed production to the limit. Previously as Meat and Wool Chairman of North Otago, I opposed Government's policies of encouraging farmers to produce more and more for less and less. In many cases under these policies, we pushed the land beyond its sustainable limits, especially under dryland conditions. High stock numbers, shallow rooting grasses and thinned out lucerne stands with bare ground between plants created ideal conditions for massive wind erosion which happened during the recent two year drought, shifting large amounts of the beautiful Hakataramea Valley out to sea. This motivated the people of the valley to set up the Kurow-Haka Resource Conservation Committee to address the present crisis and the direction of long-term land management.

\section{BACKGROUND TO LAND USE AT RIVERSIDE}

For the last 21 years I have been farming 600 hectares on the dry eastern slopes of the Valley, plus for a few years another 100 hectares (since sold and the capital invested off farm). On the 600 hectares we ran 3,700 corriedale ewes and 900 hoggets. The corriedales have been sold and we are now consolidated at 2,000 merino ewes and 1,400 drys. We are now looking at a low costlow labour system, self-sustainable, both environmentally and economically, with some extra capital being developed from the off farm investments.

The property involves two levels of river terrace with steep facings in between. Recent and young soils from greywacke alluvium and loess cover nearly $40 \%$ of the 
property, the balance being derived from older more weathered sediments, some of tertiary age with accumulations of loess on sheltered sites. The average rainfall is $430 \mathrm{~mm}$. When I shifted to Riverside it was being cropped for cereals. The light, shallow soils produced poor yields. These areas were sown down in permanent lucerne stands and produced excellent hay and pasture. Borderdyke irrigation was developed on the lower terrace. This guaranteed hay crops and fattening feed for lambs in a dry summer. Recently the borderdyke irrigation has been replaced by a more water-efficient spray irrigation system. Windbreak treeplanting was started but establishment was variable. Success has improved more recently with better techniques. On the shady faces, clover and grasses were established while the sunny faces supported only weed species. The sunny faces produced some green pickings in early spring but little else. On the poorest stony area mouse-ear hawkweed (Hieracium) has become dominant.

\section{PREVIOUS PASTURE MANAGEMENT}

New Zealand farmers are specialists in developing massive monocultures and pastures with very few species. The downlands of the Haka Valley, a very fertile but recognised drought-prone area, have for many years been largely sown out in shallow-rooting grasses and clovers which cannot survive droughts. With every drought, the ground-cover is lost, and the soil becomes exposed and vulnerable. Large areas of lucerne have also been established, and, although a deep-rooting species, the plants thin out over the years. Weeds establish between the lucerne plants, but these are either sprayed out to keep the paddock 'clean', or they die out in a drought, exposing bare ground. Frost heave or overgrazing and trampling during drought periods loosens the soil surface and the westerly winds blow topsoil from the paddocks. Over the years the loss of soil and litter has left the lucerne plants pedestalled. However, where patches of couch have spread from windbreaks, soil and litter accumulated and earthworms survived.

I realised that if the present methods of farming continued in the valley, in a few decades there would be no topsoil left. Methods such as destocking, irrigation and shelterbelts have been considered to help overcome this problem. However, destocking is economically non-viable and irrigation is a costly and continuous highenergy input which does not attack the heart of the problem of low natural rainfall, but merely compensates for this. Shelterbelts are effective but only for relatively short distances from the belt. A whole new philosphy is needed to work with nature; that is, to accept the natural conditions of the Hakataramea climate and understand how the land itself works. Farming methods can then be developed to suit this, using nature's technology rather than constantly requiring more sophisticated and expensive modern human technology.

\section{CURRENT PASTURE MANAGEMENT STRATEGIES}

The first remedy was to stop spraying the weeds from the lucerne paddocks. This reduced costs and was beneficial for stock health. It made sense to replace the weeds with a productive companion plant to complement the lucerne. This prompted a trip by myself and Alistair Shearer, then of the Waitaki Catchment Commission, to the Grassland Association Conference at Blenheim in 1982. We were so impressed with the work done on the Wether Hills, integrating phalaris with lucerne and the resultant improved ground cover, that we came home and immediately set up farm scale trials of as many known and relatively unknown'dryland grasses as we could find. In the autumn the weeds were sprayed from an old ten hectare lucerne paddock and in the spring twelve different species were overdrilled in rows across the direction of the wind. Details of this trial including production data are outlined in the 
paper by Wills ef $a$ l. in this volume.

It is an interesting trial and has been the site for numerous field days concerning wind erosion, conservation tillage and dryland plant species. Grasslands Maru phalaris, pubescent wheatgrass and tall oatgrass are particularly impressive. I have also been making palatability assessments and the trials have been extended, with assistance from Peter Aitchison of Aitchison Industries and David Musgrave of Dalgety Agresearch.

I am introducing earthworms into the top terrace paddocks. Together with my neighbours, we have acquired a machine for these purposes.

Research on dryland shrub species for soil conservation and browse in Central Otago and the Mackenzie, especially in low soil fertility situations, has been carried out by MWD since prior to 1980 with encouraging results, and now involve trials at Riverside.

During 1984, Alistair Shearer visited the USA on a Churchill Fellowship and brought back some interesting ideas; in particular, the productive use of palatable shrub species, and the management of dryland pasture species as a crop to achieve maximum sustainable production. The latter involves removing no more than $50 \%$ of growth at any grazing during the growing season and no more than $70 \%$ of herbage after the growing season. This ensures large healthy plants with a large active root mass, rapid leaf regrowth, early greening up in spring, more stable production in variable years and the ability to withstand drought and weed competition. It also leaves sufficient dry matter to protect the plant crown and form a mulch on the soil to reduce raindrop impact, improves moisture penetration, reduces runoff and improves soil moisture retention.

\section{SUNNY FACE TREATMENTS}

Observing similar climatic areas in natural grasslands throughout the world, we find that nature has adopted means to protect the land. Shrubs which are able to tolerate drought are invariably found in association with the dryland grasses. During the recent drought in the valley, good grass growth could only be found in the shelter under matagouri, brier or coprosma shrubs. Shrubs provide a canopy giving continuous shelter from winds, trap moisture around their roots and the surrounding soil, and their deep root systems help transfer nutrients to the topsoil. Grasses and shrubs work together as a team to help and protect one another.

From a farming perspective, this system has many advantages. If one can establish a grass and shrub cover together, one not only integrates feed and shelter, providing them simultaneously, but also radically increases the feed potential by using the shrubs themselves as browsing fodder. Experiments to look at the farming potential of this system have begun at Riverside in conjunction with the Waitaki Catchment Commission and the Ministry of Works and Development, Alexandra.

Trials have been extended onto a sunny face where shrub species have been space planted. These faces, which at present produce almost nothing, could show a massive lift in production with the development of appropriate multi-tiered vegetation.

The revegetation programme involves fencing off all sunny faces to separate them from adjoining flat land. Where tractor access is possible on these faces, contour lines are being ripped every $5 \mathrm{~m}$ to assist tree planting and moisture retention. Trials with shrub planting machines and direct seeding of shrub species have been started. Sowing and planting should be carried out during August or March depending on available soil moisture levels.

A mixture of appropriate legumes, grasses, herbs, palatable shrubs and shelter trees will produce standing "hay" for the August/September feed deficit and provide 
a warm sheltered site following pre-lamb shearing or for kidding and fawning. The mixed cover will also provide fodder for bees, habitat for wildlife, pest predators (including ladybirds for those aphids), protect the onsite soil and provide offsite protection by allowing the adjacent terrace lucerne paddocks to be destocked during the critical spring windblow danger period. The amount of cover will also inhibit rabbit populations. This factor seems to have been overlooked in the current rabbit control debate.

Towards the top of the slope, taller tree species such as Eucalyptus and Acacia are being planted to provide shelter on the adjacent flat terrace. Across the slope, mountain mahogany, tree lucerne (Tagasaste), tree medick and saltbush shrubs are being planted at approximately $5 \mathrm{~m}$ by $5 \mathrm{~m}$ spacings. We are currently obtaining very good growth rates from the saltbush, Atriplex halimus; it is frost hardy and its growth form seems ideal for browsing, but there again we are trying as many different shrub species as we can find (Table 1). A year after establishment of the shrubs, selected plants and fertiliser will be flown on by helicopter. This year's delay is important to allow establishment of the shrubs without competition from these vigorous plants. Immediately prior to sowing, a large mob of sheep will be used to bare the ground and cultivate the soil surface with their hooves. A suitable mixture of legumes, herbs and grasses will be oversown onto the block. Promising plants identified to date include lucerne, Lotus corniculatus, yellow sweet clover, canary clover, sheep's burnet, tall oatgrass, wheatgrass and cocksfoot. Following oversowing, a mob of sheep will be used to trample the seed into the soil. The area will receive only limited grazing for one to two years. Following this, grazing will be determined by seasonal growth rates and will be carefully monitored and controlled to avoid damage to plants. Control of rabbits and hares will be necessary.

Landscape values are an important consideration in the programme. We are trying to incorporate both the planting and fencing patterns with the general flow of the land.

Table 1: Shrubs under trial at Riverside.

\begin{tabular}{ll}
\hline Saltbush & Atriplex halimus \\
Tagasaste & Chamaecytisus palmensis \\
Mountain mahogany & Cercocarpus montanua \\
Tree medick & Medicago arborea \\
Ceanothus & Ceanothus spp. \\
Bluebush & Kochia spp. \\
canary clover & Dorycnium spp. \\
\hline
\end{tabular}

